The Cryosphere, 3, 85-99, 2009

www.the-cryosphere.net/3/85/2009/

(c) Author(s) 2009. This work is distributed under

the Creative Commons Attribution 3.0 License.

\title{
Transient thermal effects in Alpine permafrost
}

\author{
J. Noetzli and S. Gruber \\ Glaciology, Geomorphodynamics and Geochronology, Department of Geography, University of Zurich, Switzerland
}

Received: 26 February 2008 - Published in The Cryosphere Discuss.: 2 April 2008

Revised: 9 March 2009 - Accepted: 27 March 2009 - Published: 27 April 2009

\begin{abstract}
In high mountain areas, permafrost is important because it influences the occurrence of natural hazards, because it has to be considered in construction practices, and because it is sensitive to climate change. The assessment of its distribution and evolution is challenging because of highly variable conditions at and below the surface, steep topography and varying climatic conditions. This paper presents a systematic investigation of effects of topography and climate variability that are important for subsurface temperatures in Alpine bedrock permafrost. We studied the effects of both, past and projected future ground surface temperature variations on the basis of numerical experimentation with simplified mountain topography in order to demonstrate the principal effects. The modeling approach applied combines a distributed surface energy balance model and a three-dimensional subsurface heat conduction scheme. Results show that the past climate variations that essentially influence present-day permafrost temperatures at depth of the idealized mountains are the last glacial period and the major fluctuations in the past millennium. Transient effects from projected future warming, however, are likely larger than those from past climate conditions because larger temperature changes at the surface occur in shorter time periods. We further demonstrate the accelerating influence of multi-lateral warming in steep and complex topography for a temperature signal entering the subsurface as compared to the situation in flat areas. The effects of varying and uncertain material properties (i.e., thermal properties, porosity, and freezing characteristics) on the subsurface temperature field were examined in sensitivity studies. A considerable influence of latent heat due to water in low-porosity bedrock was only shown for simulations over time periods of decades to centuries. At the end, the model was applied to the to-
\end{abstract}

Correspondence to: J. Noetzli (jeannette.noetzli@geo.uzh.ch) pographic setting of the Matterhorn (Switzerland). Results from idealized geometries are compared to this first example of real topography, and possibilities as well as limitations of the model application are discussed.

\section{Introduction}

In Alpine environments, permafrost is a widespread thermal subsurface phenomenon. Permafrost is defined as material of the lithosphere that remains at or below $0^{\circ} \mathrm{C}$ for at least two consecutive years (e.g., Brown and Péwé 1973, Washburn 1979). Its possible warming and degradation in connection with climate change is regarded as a decisive factor influencing the stability of steep rock faces (e.g., Haeberli et al., 1997; Davies et al., 2001; Noetzli et al., 2003; Gruber and Haeberli, 2007). It is therefore important to assess the impact of climate change on mountain permafrost for the understanding of natural hazards and for construction practices (Haeberli, 1992; Harris et al., 2001; Romanovsky et al., 2007), especially in densely populated areas such as the European Alps. Further, permafrost influences Alpine landscape evolution, hydrology, and it is monitored in the scope of climate observing systems (e.g., Global Terrestrial Network for Permafrost, GTN-P, within the Global Climate Observing System, GCOS). The quantification of temperature changes and the discernment of zones that are sensitive to permafrost degradation require knowledge of the spatial distribution of subsurface temperatures as well as of their evolution. Even though measured temperature profiles in boreholes enable an initial assessment of temperature changes (e.g., Isaksen et al., 2007; PERMOS, 2007), they cannot be used for an extrapolation in space or time in a simple and straightforward way in high mountains (cf. Gruber et al., 2004c). The extreme topography in these areas leads to spatially highly variable surface conditions and distortions of both, direction and density of heat flow in the subsurface.

Published by Copernicus Publications on behalf of the European Geosciences Union. 
The understanding of three-dimensional and transient subsurface temperature fields below steep topography can be improved by numerical modeling that accounts for two- and three-dimensional effects (e.g., Safanda, 1999; Kohl et al., 2001; Wegmann et al., 1998).

Noetzli et al. (2007b) have shown that in complex topography ground surface temperatures (GST) alone do not sufficiently indicate the thermal conditions at depth (when speaking of "at depth" in this paper, we refer to depths deeper than the zero annual amplitude - ZAA): Because of existing lateral heat fluxes, permafrost can occur at locations with positive GST even if conditions are stationary. Stationary conditions, however, do not describe the situation found in nature since transient effects of past climate periods additionally modify the subsurface temperature field. In the Swiss Alps, permafrost thickness ranges from a few meters up to several hundreds of meters below the highest peaks (such as the Monte Rosa massif; Lüthi and Funk, 2001), and time scales involved in deep permafrost changes can be in the range of millennia even without the retarding effect of latent heat (e.g., Lunardini, 1996; Kukkonen and Safanda, 2001; Mottaghy and Rath, 2006). Consequently, the influence of past cold periods such as the last Ice Age are likely to persist in permafrost temperatures in the interior of high mountains (Haeberli et al., 1984, Kohl, 1999; Kohl and Gruber, 2003). The more recent but smaller 20th century warming (Haeberli and Beniston, 1998; Beniston, 2005) currently affects ground temperatures in the upper decameters. That is, a realistic simulation of today's thermal state of mountain permafrost cannot be based on current GST alone, but it is necessary to initialize the model far enough in the past. A corresponding initialization procedure has to include the past climate variations that influence current subsurface temperatures. Further, the modeling of transient temperature fields is essential to assess possible permafrost temperatures in the coming decades and centuries.

The combined effects of steep topography and transient paleoclimatic signals on the subsurface temperature fields in the interior of Alpine peaks have not been systematically studied so far. In this paper, we first analyze how big the influence of past climate conditions is on the present-day thermal state of mountain permafrost. And secondly, we consider a simplified scenario of future climate change in order to estimate their effect. Our study is based on numerical experimentation with simplified topography and typical values of surface and subsurface conditions because the situation in nature is highly variable and complex. The results of such idealized simulations can be used to identify the principal effects and will contribute to our understanding of the threedimensional distribution of mountain permafrost, its thermal state today, and its possible evolution in the future. They should be seen as a step towards assessing natural and more complicated situations. Results will also be useful to decide on the initialization procedure required for the modeling of permafrost temperatures in high-mountains. At the end, the model is applied to the topographic setting of the Matterhorn (Switzerland). Results from idealized geometries are compared to this first example of real topography, and possibilities as well as important limitations of the model applications are discussed.

\section{Background and approach}

\subsection{Background}

Many studies point to significant temperature depressions in the deeper subsurface, which are caused by past cold climate conditions (e.g., Haeberli et al., 1984; Safanda and Rajver, 2001). That is, actual subsurface temperatures are colder than for a stationary temperature field that corresponds to current climate conditions. The depth to which a ground surface temperature variation is perceivable is determined by its amplitude and duration, as well as by the thermal properties of the subsurface. In modeling studies, such temperature anomalies are usually computed as deviations of actual thermal conditions from equilibrium conditions (e.g., Pollak and Huang, 2000; Beltrami et al., 2005). In a first approach, they can be calculated by superposition of stepwise temperature changes using analytical heat transfer solutions (e.g., Birch, 1948; Carslaw and Jaeger, 1959). Based on this technique, an assumed $10^{\circ} \mathrm{C}$ cooler surface temperature during the last Pleistocene Ice Age (ca. 70-100 ky BP) still causes a temperature depression of more than $4^{\circ} \mathrm{C}$ at a depth of $1000 \mathrm{~m}$ (Kohl, 1999). Haeberli et al. (1984) have estimated a ground temperature depression from the last cold period of $5^{\circ} \mathrm{C}$ at a depth of about 1000 to $1500 \mathrm{~m}$ for the Swiss Plateau.

A large number of studies exist that use measured temperatures in deep boreholes to reconstruct past climatic conditions (e.g., Lachenbruch and Marshall, 1986; Pollak et al., 1998; Huang et al., 2000; Beltrami, 2001; Kukkonen and Safanda, 2001). Relating to such studies, past climate variations that have a significant influence on current subsurface temperatures can be identified. Climate reconstruction studies are, however, typically based on data measured in boreholes that were drilled in flat areas and that are principally subject to one-dimensional vertical heat transfer. Only a few recent studies deal with the effect of past temperatures together with two- or three-dimensional topography. Kohl (1999) demonstrated that the transient temperature signal can be modified by topography even at depths of more than $1000 \mathrm{~m}$. Case studies in permafrost areas in the Swiss Alps (Wegmann et al., 1998; Lüthi and Funk, 2001; Kohl and Gruber, 2003) indicate that the long term climate history has to be taken into account to realistically reproduce measured temperature fields and warming rates at depth. GST histories considered in these studies reach back in time for 1200 years for local case studies (Wegmann et al., 1998) and more than 10000 years for entire mountain massifs (Kohl et al., 2001; Lüthi and Funk, 2001). 


\subsection{Approach}

The modeling of subsurface temperatures in high-mountains is complex because temperature fields are significantly influenced by (i) spatially variable GST, (ii) spatially variable properties of the subsurface, (iii) three-dimensional effects caused by steep terrain geometry, and (iv) the evolution of GST in the past. In this study, we used and further developed the modeling procedure described by Noetzli et al. $(2007 \mathrm{a}, \mathrm{b})$, which has been designed and validated (Noetzli 2008, Noetzli et al., 2008) for use in steep mountain topography: A distributed surface energy balance model to calculate ground surface temperatures and a three-dimensional heat-conduction model are combined for forward simulation of a subsurface temperature field (Fig. 1).

Heat transfer is mainly conductive in bedrock permafrost and is driven by the spatial and temporal temperature variations at the surface and the heat flow from the interior of the earth. The distributed surface energy balance model used enables a sound calculation of spatially variable surface temperatures in steep terrain (Gruber et al., 2004b). Further processes such as advection by fluid flow can, as a first approximation, be neglected (e.g., Kukkonen and Safanda, 2001). Accordingly, we considered a purely conductive transient thermal field with the modeled surface temperatures as upper, and the geothermal heat flux as lower boundary condition. More details on the models, their validation, and their settings are given in Sect. 3 .

To account for the evolution of GST in the past, we initialize the subsurface temperature field based on a prescribed GST history using a steady state solution for the GST conditions at the start time. We applied different GST histories, which we compiled based on published changes in air temperatures and the simplifying assumption that GST follow these changes closely. That is, effects from changes in other components of the surface energy balance, snow cover, or surface characteristics are not considered. Temporal variations of surface temperatures penetrate downward with a considerable time lag and with amplitudes diminishing exponentially with depth. In this study, we ignore seasonal temperature variations, which may penetrate down to about $10-15 \mathrm{~m}$ in solid and dry bedrock (Gruber et al., 2004a), and only consider long-term variations with time scales of decades to millennia, which influence temperatures at greater depth. Such long-term variations still occur on much shorter time scales than the geological processes that determine the geothermal heat flow. The past climatologic variations are therefore treated as transient effects of the upper boundaries in our model, and the lower basal heat flow boundary condition is kept constant (cf. Pollak and Huang, 2000). The lack of information concerning the most important subsurface characteristics that influence conductive heat transport (thermal properties, porosity, freezing characteristics, etc.) is approached by using model assumptions based on sensitivity studies.

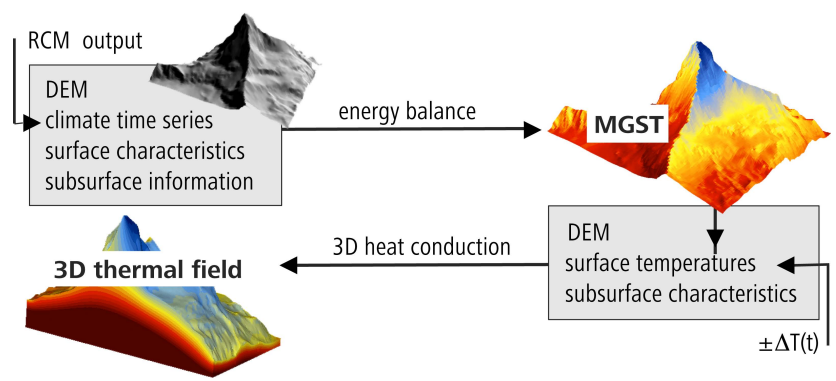

Fig. 1. Mean ground surface temperatures (MGST) are calculated based on a surface energy balance model (TEBAL). They are used as upper boundary condition in a three-dimensional finite element heat conduction scheme (within COMSOL) to compute the subsurface temperature field. For transient simulations the evolution of the surface temperatures is prescribed.

We performed the basic simulations for a simplified ridge, the most common feature comprising Alpine topography (cf. Noetzli et al., 2007). A ridge of $1000 \mathrm{~m}$ height was set to an elevation of $3500 \mathrm{~m}$ a.s.l. and east-west orientation. Hence, it has a warm south-facing and a cold north-facing slope, which induces a subsurface temperature field with steeply inclining isotherms in the uppermost part (cf. Fig. 3). A threshold for the slope of steep bedrock is often set at about $37^{\circ}$ (e.g., Gruber and Haeberli, 2007). Couloirs with this steepness, however, can often contain a significant amount of snow or debris, and because we do not consider any surface cover in the idealized settings, we set the slope value to $50^{\circ}$. In order to study the influence of terrain geometry, we varied the topographic factors (i.e., elevation and slope angle) of the two-dimensional ridge. Finally, we compared the results for a ridge topography to those for a flat and one-dimensional plain and a three-dimensional mountain peak represented by a pyramid. The use of a distributed energy balance approach is not essential for the experimentation presented here, and a reasonable parameterization for GST would suffice. For model application to more complex topography, however, the spatial distribution of GST cannot be easily parameterized and its sound calculation is crucial, because it drives the direction and magnitude of subsurface heat fluxes (Gruber et al., 2004c; Noetzli et al., 2007). For consistency and in order to demonstrate the entire modeling procedure, GST are calculated based on the distributed energy balance model for simulations with both, idealized and real topography.

\section{Temperature modeling}

\subsection{Energy balance and rock surface temperatures}

The TEBAL model (Topography and Energy BALance) simulates distributed surface energy fluxes in complex terrain based on observed climate time series, topography, and surface and subsurface information. The model is designed 
Table 1. Surface and subsurface properties assumed in the experimentation runs.

\begin{tabular}{lll}
\hline Surface & & \\
\hline Emissivity & 0.96 & Gruber et al., 2004c \\
Rougness & $0.0001 \mathrm{~m}$ & Gruber et al., 2004c \\
Albedo & 0.2 & Gruber et al., 2004c \\
\hline Subsurface & & \\
\hline Volum. heat capacity & $2.0 \times 10^{6} \mathrm{~J} \mathrm{~m}^{-3} \mathrm{~K}^{-1}$ & Cermak and Rybach, 1982; Wegmann et al., 1998 \\
Thermal conductivity & $2.5 \mathrm{~W} \mathrm{~K}^{-1} \mathrm{~m}^{-1}$ & Cermak and Rybach, 1982; Wegmann et al., 1998 \\
Porosity (saturated) & $3 \%$ & Wegmann et al., 1998 \\
\hline
\end{tabular}

(Gruber, 2005; Stocker-Mittaz, 2002) and validated (Gruber, 2005; Gruber et al., 2004b; Noetzli et al., 2007b) for the calculation of near-surface temperatures in steep rock slopes in the Alps and was successfully applied in previous studies on bedrock permafrost (e.g., Gruber et al., 2004a, b; Noetzli et al., 2007b; Salzmann et al., 2007). Mean ground surface temperatures (MGST) are computed using gridded digital elevation models (DEMs) of the topography considered and with hourly climate time series from a high elevation meteo station. In this paper, we used the data from Corvatsch at $3315 \mathrm{~m}$ a.s.1. in the Upper Engadine (Data source: MeteoSwiss) for the period 1990-1999 AD. We further reference this period as "today" or "present". Surface and subsurface properties for bedrock were set to typical values of Alpine rock according to Noetzli et al. (2007a; Table 1). The influence of their possible variation was additionally assessed in sensitivity studies (cf. Sects. 4.1.2 and 4.2.2.) For simplification purposes and because most steep rock slopes do not accumulate a thick snow cover during winter, we neglect the simulation of the snow cover for the numerical experiments.

\subsection{Heat conduction and subsurface temperatures}

As described above (Sect. 2.2), we considered a conductive three-dimensional transient thermal field (Carslaw and Jaeger, 1959) in an isotropic and homogeneous medium under complex topography. The thermal properties of the subsurface were set based on published values (Cermák and Rybach, 1982; Wegmann et al., 1998; Safanda, 1999) (cf. Table 1).

Ice contained in the pore space and crevices delays the response to surface warming by the consumption of latent heat, which may influence the time and depth scales of permafrost degradation by orders of magnitude even in low porosity rock (Wegmann et al., 1998; Romanovsky and Osterkamp, 2000; Kukkonen and Safanda, 2001). This effect can be handled in heat transfer models by introducing an apparent heat capacity. We used the approach described by Mottaghy and Rath (2006): The apparent heat capacity substitutes the heat capacity in the heat transfer equation within the freezing interval $w$. The freezing interval $w$ describes the temperature range, where phase transition takes place and unfrozen water is present, and which relates to the steepness of the unfrozen water content curve. The parameter $w$ makes it possible to account for a variety of ground conditions (Mottaghy and Rath, 2006): Values of $w$ typically range from $0.5 \mathrm{~K}$ for material such as sand to $2 \mathrm{~K}$ for material such as bentonite (Anderson and Tice, 1972; Williams and Smith, 1989), but information on bedrock material is sparse. Wegmann (1998) found that most of the interstitial ice in the rock of the Jungfrau East Ridge, Switzerland, freezes at $-0.3^{\circ} \mathrm{C}$, which indicates a small freezing interval with a steep curve and a low value of $w$. A further important factor is the porosity of the material, for which we assumed $3 \%$ (volume fraction, saturated conditions) to be a reasonable value to investigate the principal effects (cf. Wegmann et al., 1998).

The commercial finite-element (FE) modeling package COMSOL Multiphysics was used for forward modeling of subsurface rock temperatures (Noetzli et al., 2007a). The heat conduction module included in this software has been successfully used for the simulation of borehole temperature profiles in the Schilthorn ridge, Switzerland (Noetzli et al., 2008) and the Zugspitze, Germany (Noetzli, 2008). The FE mesh for the topographies was created with increasing vertical refinement from $250 \mathrm{~m}$ at depth to $10 \mathrm{~m}$ for elements closest to the surface. In order to avoid effects from the model boundaries, a rectangle box of $2000 \mathrm{~m}$ height and thermal insulation at its sides was added below the geometry. The FE mesh consisted of ca. 1500 elements for a ridge, and of about 25000 elements for a pyramid. The lower boundary condition was set to a uniform heat flux of $80 \mathrm{~mW} \mathrm{~m}^{-2}$ (Medici and Rybach, 1995), and for the upper boundary conditions the modeled MGSTs were given. The model was run with time-steps of 1 year for simulations over a period of more than 1000 years, and with time steps of 10 days for shorter periods. Sensitivity runs with higher refinement of the FE mesh, a lower boundary condition set at greater depth, and smaller time steps did not considerably change any of the results (i.e., the maximum absolute difference in modeled temperatures was below $0.1^{\circ} \mathrm{C}$ ).

The modeling procedure bases on the coupling of the distributed energy balance model TEBAL with subsurface heat 


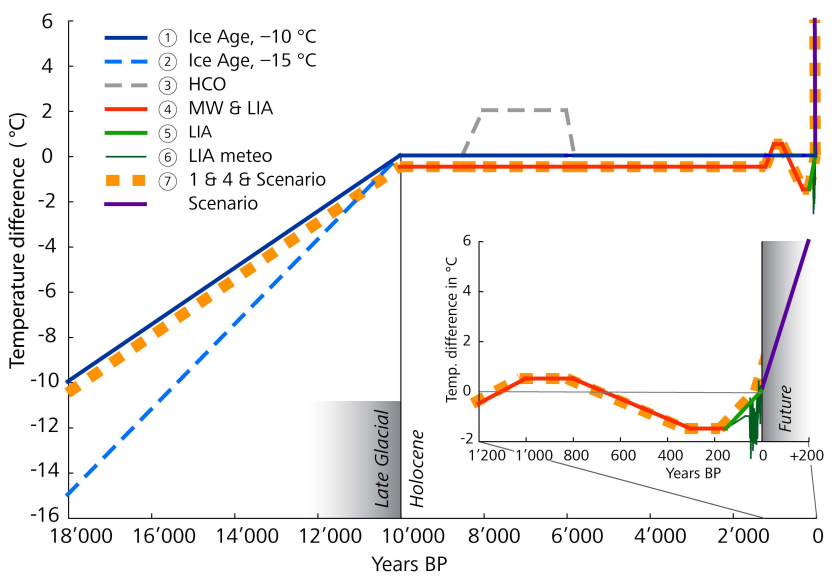

Fig. 2. For the initialization runs, surface temperature histories of diverse lengths and temporal resolutions were used. Based on the results obtained, an initialization curve for further simulations was compiled (thick dashed orange line). Scenarios were calculated assuming a uniform linear warming of $+3^{\circ} \mathrm{C} / 100 \mathrm{y}$. MW=Medieval Warmth, $\mathrm{HCO}=\mathrm{Holocene}$ Climate Optimum, LIA=Little Ice Age.

conduction simulated in COMSOL. Because measurements of entire three-dimensional temperature fields in mountains are hardly feasible, three different validation steps have been taken in order to gain confidence in the modeling results (Noetzli, 2008). They include: (1) comparison with field data measured at or near the surface, (2) comparison with temperature profiles from boreholes, and (3) sensitivity studies. For (1) and (2) we refer to the detailed descriptions and results presented in Gruber et al. (2004b), Noetzli et al. (2007), Noetzli (2008), and Noetzli et al. (2008). Sensitivity studies to assess the uncertainties related to the lack of information on subsurface properties and the surface temperature history are part of this paper (cf. Sect. 4 for results).

\subsection{Evolution of surface temperature}

A wealth of literature exists on temperature reconstructions from proxy data for global (Pollak et al., 1998; Huang et al., 2000; Jones and Mann, 2004), hemispheric (Jones et al., 1998; Petit et al., 1999), and regional scale (Patzelt, 1987; Isaksen et al., 2000; Casty et al., 2005) over the past centuries and millennia. For the European Alps, temperature variations are generally more pronounced with larger amplitudes compared to those averaged globally or for the Northern Hemisphere (Beniston et al., 1997; Pfister, 1999; Luterbacher et al., 2004). In the uppermost kilometers of the Earth's crust, mainly the thermal effects of two events are prominent today (Haeberli et al., 1984): the temperature depression during the Pleistocene Ice Age and the sharp rise in temperatures between the time of maximum glaciation (around $18 \mathrm{ky} \mathrm{BP}$ ) and the beginning of the thermally more stable Holocene (around $10 \mathrm{ky} \mathrm{BP}$ ). For the Holocene, the Climatic Optimum (HCO, ca. 5-6 ky BP), the Medieval Warmth (MW, ca. 800-

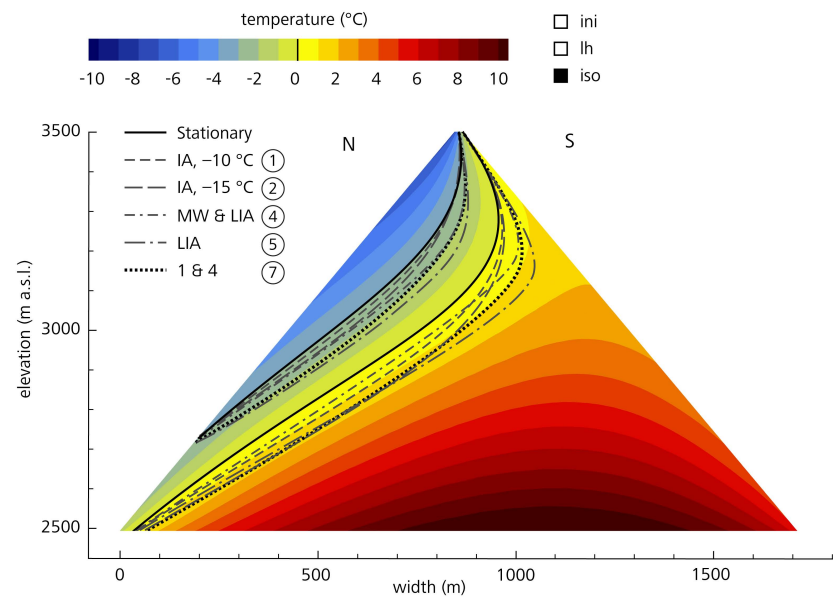

Fig. 3. Difference in the subsurface temperature field for a stationary simulation compared to model runs initialized with different surface temperature histories: The $0^{\circ} \mathrm{C}$ and $-3^{\circ} \mathrm{C}$ isotherms for the different model runs are plotted over the stationary solution depicted in color.

1300 AD), the Little Ice Age (LIA, ca. 1300-1850 AD), and the subsequent 20th Century warming are typically resolved in temperature reconstructions (cf. Dahl-Jensen et al., 1998). With increasing spatial and temporal refinement, climate variations become more complex and reconstructions more detailed, particularly towards the present time. This meets our needs since due to the diffusive nature of heat flow a temperature signal entering into the subsurface is dampened with depth. That is, the temporal resolution of the surface temperature variations affecting subsurface temperatures decreases with depth.

We analyze the influence of the above-mentioned periods (Fig. 2) on the present-day subsurface temperature field inside steep mountains. The effects of temperature variations further back in time or of smaller amplitude are considered negligible. For a detailed description of the most recent temperature fluctuations we used measured variations in mean annual air temperatures (MAAT) from a high Alpine station (Jungfraujoch, Switzerland, $3576 \mathrm{~m}$ a.s.l.), where air temperature data is available back to 1933 AD (Data Source: MeteoSwiss). The difference in mean temperatures between the periods 1990-1999 AD and 1933-1950 AD amounts to $+1^{\circ} \mathrm{C}$ for this station. Additionally, we assumed a difference in air temperature of $+0.5^{\circ} \mathrm{C}$ between the end of the LIA and the start of the data recordings, resulting in a total increase of $+1.5^{\circ} \mathrm{C}$ since $1850 \mathrm{AD}$ (cf. Boehm et al., 2001).

Based on the above described considerations, we explore the effect of the following scenarios of temperature history in order to decide on the initialization procedure (Fig. 2):

- The Pleistocene Ice Age (1)/(2); numbers in brackets correspond to Fig. 2): Temperature depressions are assumed $-10^{\circ} \mathrm{C}$ colder compared to present-day 
temperatures (Patzelt, 1987), followed by a linear increase from the time of maximum glaciation (18 ky BP) to the beginning of the Holocene (10 ky BP). For the Holocene no temperature variations were considered. To assess the effect of colder estimates, we additionally used a value of $-15^{\circ} \mathrm{C}$ (Haeberli et al., 1984).

- $H C O$ (3): During the Holocene Climate Optimum summer temperatures were approx. $1.5-3^{\circ} \mathrm{C}$ warmer than today (Burga, 1991). Mean annual temperatures probably were not as high, but to test the influence of this period we assumed $+2^{\circ} \mathrm{C}$.

- Past millennium (4): In contrast to e.g., von Rudloff (1980), newer studies conclude that air temperatures in Europe during the MW were probably not warmer than or comparable to today (Hughes and Diaz, 1994; Crowley and Lowery, 2000; Goosse et al., 2006). Yet, to estimate the possible influence of the MW we used $0.5^{\circ} \mathrm{C}$ higher surface temperatures than at present. For the LIA, we assumed temperatures $1.5^{\circ} \mathrm{C}$ lower (Boehm et al., 2001).

- Recent warming: We used a linear temperature increase following the LIA (5) and, in addition, annual MAAT variations taken from Jungfraujoch meteodata (6).

Further, to asses the transient response of the subsurface temperature field to future warming, we used a warming scenario of the rock surface of $+3^{\circ} \mathrm{C} / 100 \mathrm{y}$. This value has been calculated as a mean warming of Alpine rock surfaces from 1982-2002 to 2071-2091, based on output from different Regional Climate Models, different emission scenarios, downscaling methods, and varying topographic settings by Salzmann et al. (2007). Since no information on the form of the increase (e.g., exponential) was deducted and uncertainties are high, we chose a linear increase. Based on this simple scenario, the principal effects of the transient response of bedrock temperatures can be investigated.

\section{Transient temperature fields below idealized topography}

\subsection{Effects of past climatic conditions}

If not indicated otherwise, results are discussed and visualized for a ridge cross section of $1000 \mathrm{~m}$ height with a maximum elevation of $3500 \mathrm{~m}$ a.s.l., and a slope angle of $50^{\circ}$; the subsurface material is assumed homogenous and isotropic, and no latent heat is considered. Variations from these basic settings are mentioned in the text and indicated in the figures with checkboxes and corresponding abbreviations (i.e., $i n i$ for initialized, $t h$ for latent heat considered, and iso for isotropic subsurface conditions).

The stationary temperature field describes the general character of the subsurface temperature pattern of the ridge, which does not fundamentally differ for temperatures resulting from initialized model runs. The latter, however, are lower for the entire thermal field and all GST histories used. $0^{\circ} \mathrm{C}$ and $-3^{\circ} \mathrm{C}$-isotherms of temperature fields initialized with different GST histories are compared to stationary conditions with current GST in Fig. 3: According to the definition of permafrost, the $0^{\circ} \mathrm{C}$ isotherm stands for the schematic permafrost boundary in the idealized mountain ridge, whereas the $-3^{\circ} \mathrm{C}$ isotherm relates to the temperature distribution inside the schematic permafrost body. The resulting temperature depressions from the last Ice Age (1) is in the range of $-0.5^{\circ} \mathrm{C}$ for the upper half of the geometry, and in the range of $-2.5^{\circ} \mathrm{C}$ for the lower part. When assuming colder GST in the last Ice Age (2) these values amount to $-1^{\circ} \mathrm{C}$ and $-4^{\circ} \mathrm{C}$, respectively. Simulating the GST variations during the Holocene (4) results in additionally lower temperatures: On the one hand, the LIA (5) is perceivable down to about $250 \mathrm{~m}$ depth. On the other hand, deeper parts are modeled colder because (1) and (2) do not consider that present-day GST are somewhat higher than Holocene average. The effect of the $\mathrm{HCO}(3)$ is below $0.1^{\circ} \mathrm{C}$ for the entire geometry, and results are therefore not displayed in Fig. 3. Results for GST history (6) do not notably differ from (5) and are not shown, either. Based on the results from (1) to (6), we compiled GST history (7), which accounts for the variations for which a significant influence was shown above. Although we use highly idealized conditions in the experiments, it can be assumed that these are the most important variations that influence the subsurface thermal field in high mountains, because thermal properties and size of the major part of Alpine topography does not essentially differ from the geometries used: We considered the cold temperatures during the last Ice Age (1) and the major fluctuations in the past millennium (4). GST history (7) is used for all subsequent calculations in this study and corresponding temperature fields are referred to as "initialized" or "transient".

Figure 4 depicts the isotherms of the initialized temperature pattern together with the stationary field for current GST. The initialized temperature field is colder and in the uppermost $100 \mathrm{~m}$ the recent warming since the LIA is clearly visible. In the middle part of the warmer side of the ridge, the inclination of the isotherms is reversed. In this part of the geometry, we identify the biggest differences compared to stationary conditions. The absolute temperature difference of a transient to a stationary thermal field for present-day GST is plotted in Fig. 5. Maximum calculated temperature depressions in the innermost parts of the geometry are $-3^{\circ} \mathrm{C}$, whereas the temperature depression does not exceed $1^{\circ} \mathrm{C}$ in the upper half of the geometry. The MW and the fact that the LIA has not yet penetrated to great depth cause the warmer area visible in the top center of the ridge (Fig. 5). 


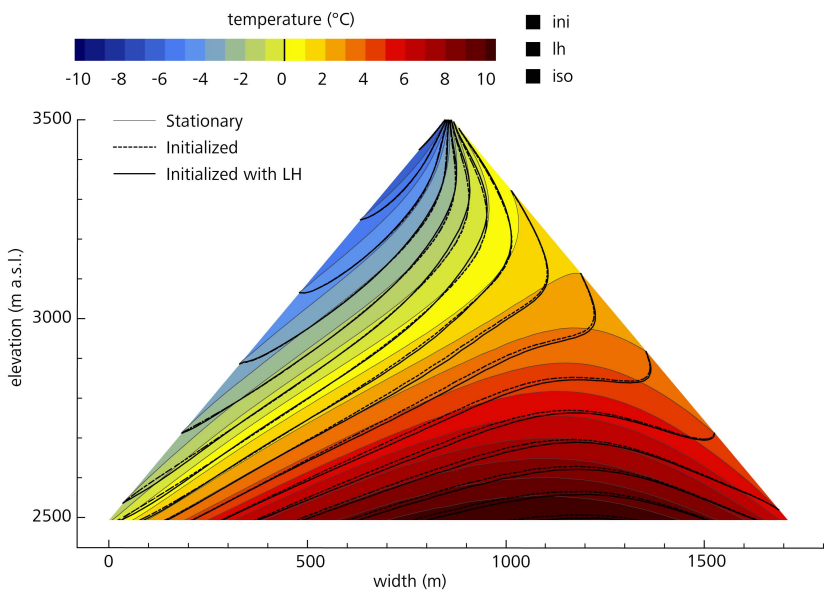

Fig. 4. The isotherms of a stationary temperature field (thin grey lines and background colors) compared to an initialized one (temperature history (7) from Fig. 2). The transient temperature field is shown for simulations both with (solid line) and without (dotted line) considering the effects of latent heat. The porosity was set to $3 \%$.

\subsubsection{Topography}

For simulations based on conduction only, the elevation of the geometry changes the absolute temperature field but not its pattern. The temperature depressions given above are thus valid for ridge-topographies of any elevation, but the position of the $0^{\circ} \mathrm{C}$ isotherm varies (Fig. 5). The corresponding difference in thickness (which we consider vertical to the surface) of the "permafrost zone" in the simplified ridge (in brackets because we have not looked at a real situation in nature but at idealized geometries) between stationary and transient results increases for higher mountains with thicker "permafrost". For the highest example shown in Fig. 5 ( $4500 \mathrm{~m}$ a.s.1.), the difference amounts to more than $100 \mathrm{~m}$. For the lowest example ( $3000 \mathrm{~m}$ a.s.l.) it is in the dimension of decameters.

Convex topography accelerates the reaction of the subsurface temperature to changing surface conditions. Firstly and more obviously, the distance a signal has to penetrate to reach the interior of the mountain is shorter than in flat terrain. The steeper the topography, the shorter is this distance. In addition to this effect, the warming signal reaches a point in the interior from more than one side, that is, from two sides in the case of a ridge, and from four sides in a pyramid-like situation. To demonstrate this effect of multi-lateral warming, we compare the temperature depressions in $\mathrm{T}(\mathrm{z})$-profiles in a flat one-dimensional plane, a two-dimensional ridge, and a three-dimensional pyramid (Fig. 6). For the two- and three-dimensional geometries, the profiles are extracted vertically from the top of the geometry. The resulting temperature depression, however, was not plotted versus the length of the profile, but versus the shortest distance of the profile

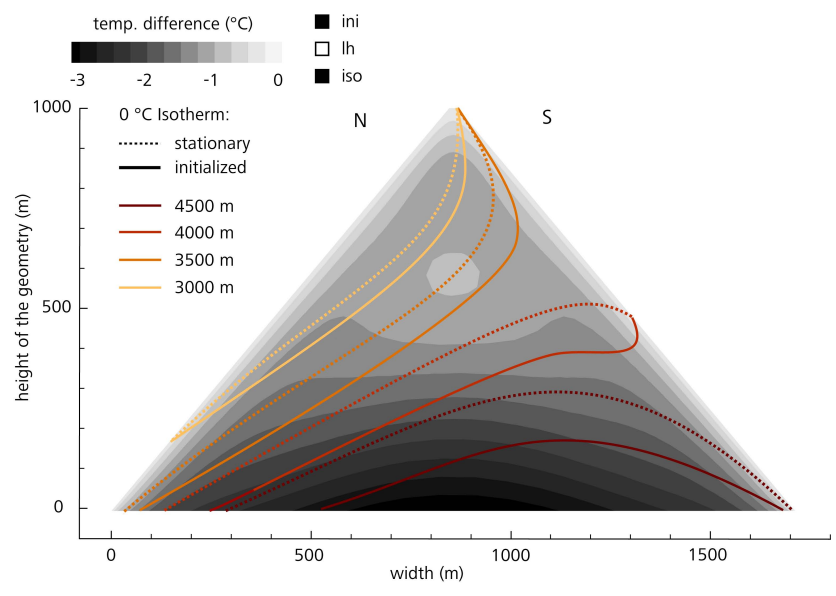

Fig. 5. The difference of the stationary solution to an initialized one (temperature history 7 from Fig. 2) is shown in gray colors. The lines indicate the permafrost boundary for the stationary (dotted line) and the transient (solid line) simulation, respectively, for four different maximum elevations of a ridge ranging from 3000 to $4500 \mathrm{~m}$ a.s.l. Colors indicate different elevations.

to the surface (i.e., the distance, the signal has to penetrate, cf. schematic plots in Fig. 6). In this way, multi-lateral warming causes the effect shown, and not the fact that the distance to the surface is shorter than the depth of the profile. For the two mountain geometries the modeled temperature depression is roughly half of that for a flat plane in the $200 \mathrm{~m}$ closest to the surface. For the deeper parts (i.e., $300 \mathrm{~m}$ and more), the difference increases and ca. $-3^{\circ} \mathrm{C}$ for flat terrain contrast with ca. $-1^{\circ} \mathrm{C}$ for two- and three-dimensional mountain topography. The effect of the three-dimensional compared to the two-dimensional geometry is small for the long time scale of the initialization and the depth range shown. This is due to the fact that the major part of the temperature signal has reached the depths shown in both mountain geometries (cf. also Sect. 4.2 and Fig. 9).

\subsubsection{Subsurface properties}

Information about subsurface properties of bedrock (such as thermal properties, porosity, and freezing characteristics) is sparse for natural conditions in high mountains. In order to gain confidence in the modeling results, we tested their possible influence in sensitivity studies.

Energy consumption due to latent heat is of minor importance for low porosity material and for the time (i.e., millennia) and depth (i.e., ca. $500 \mathrm{~m}$ from the surface) scales considered in the idealized simulations (Fig. 5): subsurface temperatures are slightly colder compared to simulations without latent heat, but differences do not exceed $0.2^{\circ} \mathrm{C}$ at depth. This is in accordance with calculations by Haeberli et al. (1984) and model experiments published by Mottaghy and Rath (2006). The effect of latent heat becomes much more important for transient simulations over shorter 


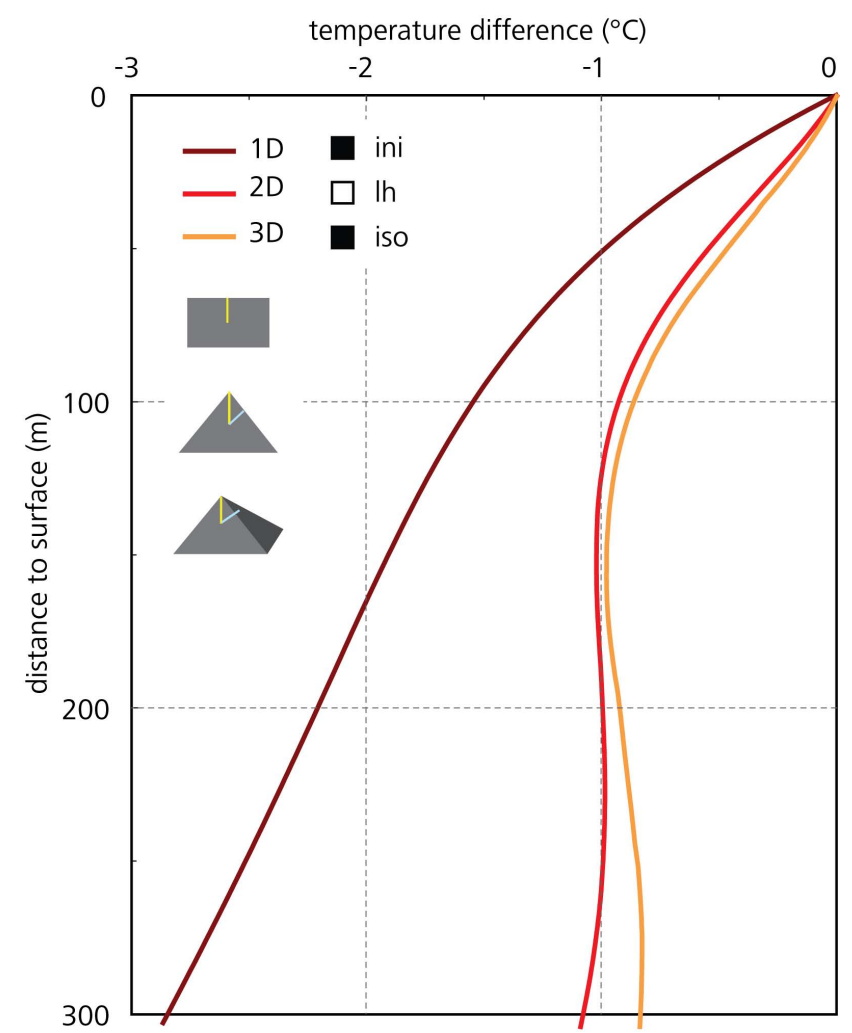

Fig. 6. Temperature depression in the subsurface thermal field of today caused by colder past surface temperatures for one- (flat terrain), two- (ridge), and three-dimensional (pyramid) situations. In the two- and three-dimensional situations, profiles are extracted vertically from the top of the geometry. Temperature differences are plotted versus the shortest distance to the surface, i.e., the distance the temperature signal penetrated.

time periods (i.e., centuries, see Sect. 4.2.2) or for considerably higher porosities. In mountain permafrost areas, high ice contents may be present in the near surface layer, where porosity is often increased due to weathering and fracturing. For example, the ice content of the Schilthorn crest, Switzerland, is estimated to be roughly $10-20 \%$ in the upper meters and around 5\% in the deeper parts (e.g., Scherler, 2006, Hauck et al., 2008). For this reason, we examined the concept of the influence of conduction through an upper layer with a higher ice-content on the transient temperature field below. We added a $15 \mathrm{~m}$ thick layer with $20 \%$ porosity as a surface layer to the ridge geometry. Yet, no considerable difference to the simulations with homogenous porosity for the entire ridge resulted. However, it must be emphasized at this place that other processes than conduction and phase change are not considered and are likely to play an important role in such a weathered layer (e.g., Scherler, 2006).

Thermal conductivities of bedrock often show large variations due to anisotropy (e.g., in gneiss). Values for the anisotropy factor of crystalline rocks are typically between 1.2 and 2 (Schoen, 1983; Kukkonen and Safanda, 2001). In

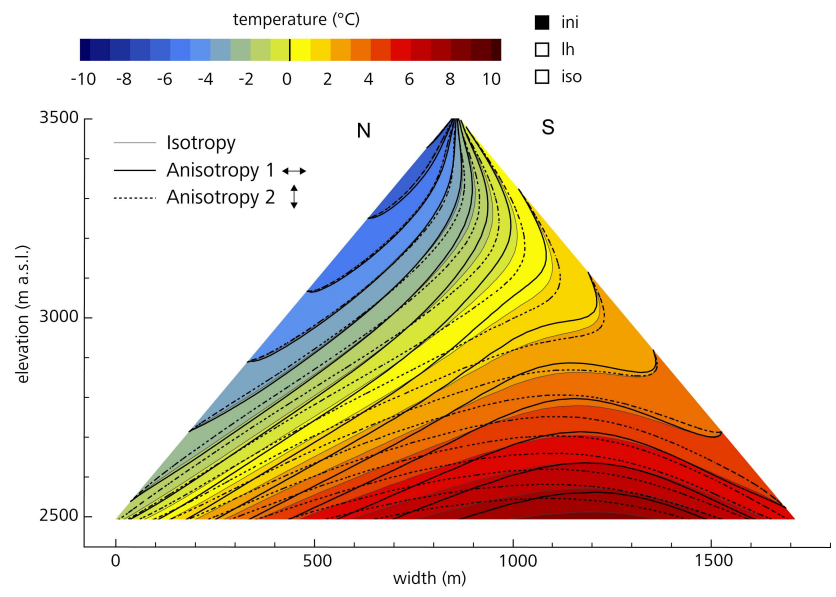

Fig. 7. Transient temperature field of an isotropic medium (background colors, gray lines) compared to anisotropic mediums with increased horizontal (anisotropy 1, solid lines) and vertical (anisotropy 2, dotted lines) thermal conductivity, respectively.

order to investigate the anisotropy effect on the temperature field we performed model runs with thermal conductivity increased both, horizontally and vertically: In a first run, the thermal conductivity was set to $2 \mathrm{~W} \mathrm{~K}^{-1} \mathrm{~m}^{-1}$ in $\mathrm{x}$-direction and to $3 \mathrm{~W} \mathrm{~K}^{-1} \mathrm{~m}^{-1}$ in the perpendicular $\mathrm{z}$-direction direction. For the second run, the vertical and horizontal thermal conductivities were swapped (i.e., the anisotropy factor was set to 0.66 in the first and to 1.5 in the second run). An increased horizontal thermal conductivity supports lateral heat fluxes and the effect of steep topography, whereas an increased vertical component reduces it. The latter has a bigger effect on the modeled temperatures in the interior of the geometry and increases the effect from past climate conditions: Differences to isotropic conditions amount up to $-2^{\circ} \mathrm{C}$ for increased vertical thermal conductivity, and $0.5^{\circ} \mathrm{C}$ for increased horizontal conductivity (Fig. 7).

The heat capacity of bedrock typically ranges from about 1.8 to $3 \times 10^{6} \mathrm{~J} \mathrm{~kg}^{-1} \mathrm{~K}^{-1}$ (Cermák and Rybach, 1982). Test runs with varying values result in a maximum difference of less than $1{ }^{\circ} \mathrm{C}$ for the inner part of the ridge geometry. The geothermal heat flux has only a small influence on the stationary subsurface temperature field inside steep mountain peaks (Noetzli et al., 2007b). This is also true for the transient calculations presented here: Resulting temperature depressions from simulations with a zero heat flux lower boundary condition were assessed to differ less than $0.2^{\circ} \mathrm{C}$. Further, we tested the influence of radiogenetic heat production. Values for rock are given between 0.5 and $6 \mu \mathrm{W} \mathrm{m}^{-3}$ (Kohl, 1999). We used a medium value of $3 \mu \mathrm{W} \mathrm{m}^{-3}$ for a test run. Maximum differences to results without heat production were assessed to be below $0.5^{\circ} \mathrm{C}$ for the entire ridge geometry, and below $0.1^{\circ} \mathrm{C}$ for the upper half. 


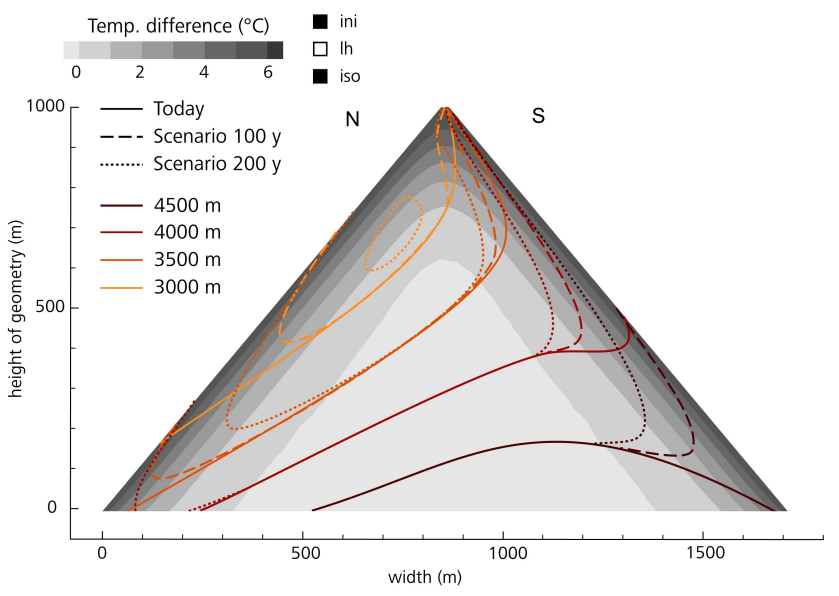

Fig. 8. The temperature difference between the current transient temperature field and a 200-year scenario simulation is displayed in gray shadings. The warming has penetrated to ca. $250 \mathrm{~m}$ depth. The evolution of the $0^{\circ} \mathrm{C}$ isotherms for a 200-year scenario is plotted for different elevations of the ridge. Colors indicate different elevations, whereas the dotted patterns represent the situation today (solid lines), in 100 years (dashed lines), and in 200 years (dotted lines).

\subsection{Effects of future warming}

The effect of a linear temperature rise at the surface of $+3^{\circ} \mathrm{C} / 100$ y during 200 years on the subsurface thermal field in steep topography has been shown in numerical experiments by Noetzli et al. (2007b). The results showed that the warming has penetrated to a depth of approximately $250 \mathrm{~m}$ after 200 years, but only about $50 \%$ of the temperature change has reached a depth of more than $100 \mathrm{~m}$. Temperatures at greater depth than ca. $250 \mathrm{~m}$ still remain unchanged after 200 years. Further, a retarding influence of latent heat was demonstrated. In this study, we look at the idealized response of thermal fields in high mountains to possible future temperature changes that are caused by elevation, geometry, and subsurface conditions.

\subsubsection{Topography}

In Fig. 8, the state of the schematic permafrost body inside the ridge geometry is displayed for the situation after following the linear temperature scenario for 200 years and different elevations. The position of the $0^{\circ} \mathrm{C}$ isotherm at $250 \mathrm{~m}$ or closer to the surface changes drastically and is bent towards the top. On the warmer side of the geometry, the isotherms first change to run more or less parallel to the surface and then move rather uniformly towards the colder side. For all elevations, no below zero temperatures, or "permafrost", remain at the surface on the southern slope of the idealized geometry. Nevertheless, a significant "permafrost body" remains below the surface for a long time, especially for higher elevations. For lower elevations a "permafrost body" remains only on the colder side.

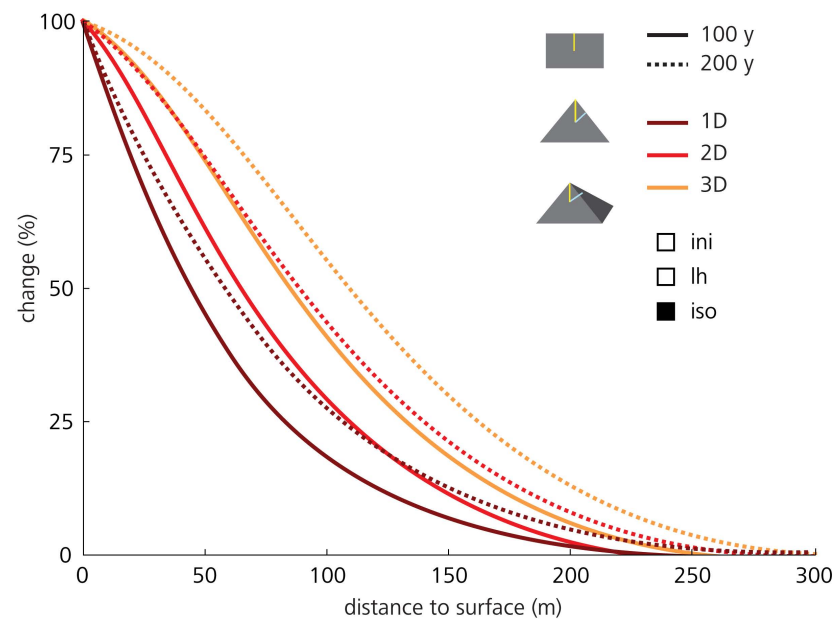

Fig. 9. Percent of a temperature signal at the surface that has penetrated to depth: This effect is shown for a one- (flat terrain), two- (ridge), and three-dimensional (pyramid) situation after 100 (solid lines) and 200 years (dotted lines). In the two- and threedimensional situations values are plotted versus the shortest distance to the surface.

The above-described (Sect. 4.1.1) effect of multi-lateral warming is also significant for shorter time periods. Figure 9 displays the percentage of a surface temperature signal that has reached a certain depth after 100 and 200 years. For example, $50 \%$ of the temperature signal has reached a depth of about $60 \mathrm{~m}$ after 200 years in a one-dimensional vertical simulation. In the two-dimensional situation, $50 \%$ of the signal has already penetrated to about $90 \mathrm{~m}$, and in the threedimensional situation to ca. $115 \mathrm{~m}$. In the same way as in Fig. 6, values for the two- and three-dimensional geometries are plotted versus the shortest distance to the surface, rather than versus the length of the profile.

\subsubsection{Subsurface conditions}

The effect of latent heat on the temperature fields subject to the idealized future scenario is illustrated in Fig. 10. It leads to a considerably slower decrease of the zone with below zero temperatures. With varying freezing range (parameter $w$ ) the size of this zone does not change significantly, but the temperature distribution in it does. A smaller value of $w$ (i.e., a smaller freezing range and a steeper unfrozen water content curve) keeps the thermal field for a longer time period in the temperature ranges little below the melting point. This leads to more homogeneous temperature fields than when modeled with a larger value of $w$. When looking at T(z)profiles from synthetic boreholes of the geometry, this results in steeper profiles and smaller temperature gradients with depth (Fig. 11). For example, this effect can be observed in the temperature profiles of the two $100 \mathrm{~m}$ deep boreholes on the Schilthorn crest ( $2970 \mathrm{~m}$ a.s.l., Switzerland), which are entirely in the range of -2 to $0^{\circ} \mathrm{C}$ (cf. Noetzli et al., 2008). 


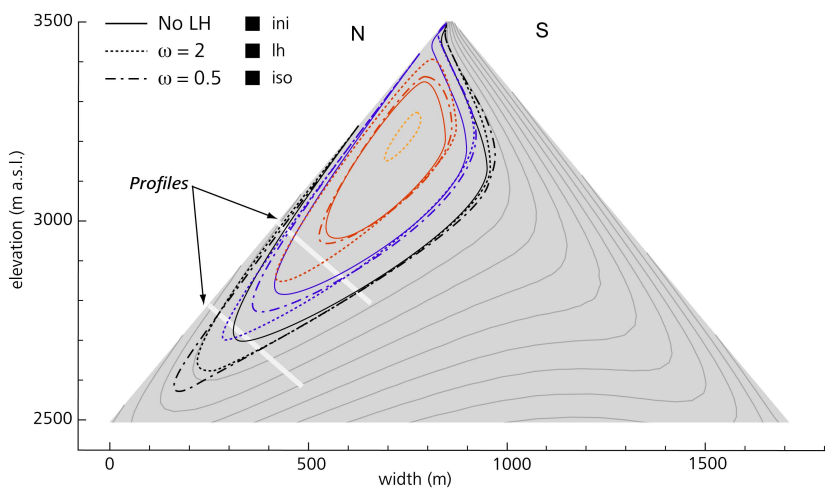

Fig. 10. The permafrost body in a ridge calculated for a 200-year scenario is displayed for simulations with and without considering the effects of latent heat and a porosity of $3 \%$. Additionally, different values of the parameter $w$, which describes the unfrozen water content curve, have been considered. Black lines represent the modeled $0^{\circ} \mathrm{C}$ isotherm, i.e., the remaining permafrost body; blue, red, and yellow lines the $-1,-2$, and $-3^{\circ} \mathrm{C}$ isotherms.

This points to subsurface material with a small freezing interval and a low value of $w$. The observed higher ice-content in the near-surface layer (cf. Sect. 4.1.2) can act as a buffer to temperature changes at the surface and further delay the short-term reaction of the subsurface temperature field, when looking at time scales of the next 1-2 centuries (Fig. 11).

\section{Application to the topographic setting of the Matterhorn}

The Matterhorn (4478 ma.s.l.) in Switzerland is probably the most prominent mountain peak in the European Alps. Its distinctive topography resembles a pyramid of about $1500 \mathrm{~m}$ height with faces exposed to the four main orientations. Slope angles are $>45^{\circ} \mathrm{C}$ for most parts and only isolated or thin patches of snow persist on the rock. With its extreme three-dimensional geometry, the Matterhorn constitutes a prime example for an application of the presented modeling approach to real topography. The application of the modeling procedure to the Matterhorn topography is seen as a step towards more natural conditions. Further, it is helpful to intuitively understand the dimensions of changes shown in the results from idealized geometries. Based on the experience gained with the previous experiments and the validations conducted (see Sect. 3.2), the modeling procedure allows to describe the principal pattern of the subsurface temperature and permafrost distribution inside the mountain and how they may evolve in the future. However, results need to be interpreted with great care, especially where a considerable snow or glacier cover influences the ground temperatures (cf. Sect. 6). For a detailed description and the requirement to accurately model subsurface temperatures, the modeling has to be calibrated and tested against measured

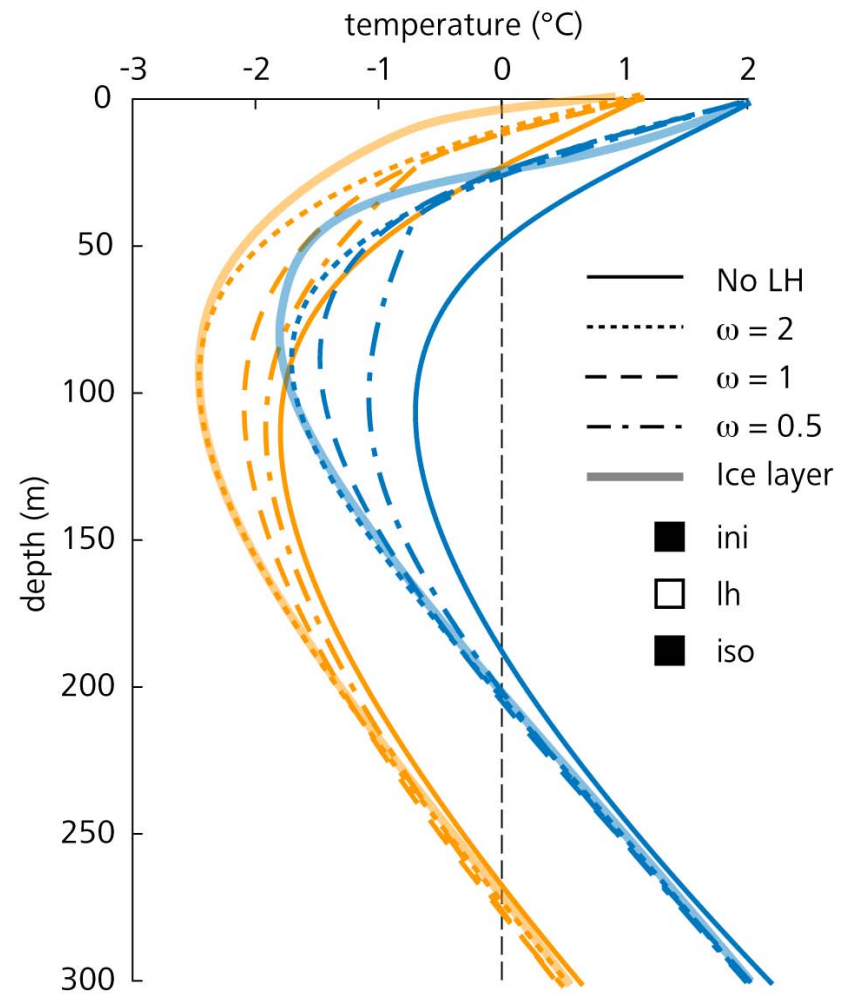

Fig. 11. $T(z)$-profiles of two synthetic boreholes vertical to the slope in the middle and the lower part of the North side of a ridge (cf. Fig. 10) illustrate the effect of latent heat and the freezing range $w$. In addition, thick bright lines display the profile of a simulation with a $20 \mathrm{~m}$ ice-rich layer at the surface.

data from the Matterhorn. Several measurement sites have recently been instrumented and corresponding datasets will be available soon. Temperature data are measured on the Hörnli Ridge (NE ridge: two $60 \mathrm{~m}$ boreholes close to the Hörnlihütte that are monitored within the PERMOS project (PERMOS, 2007), and extensive thermal and geotechnical measurements at the 2003 rock fall scar within the project PermaSense; Hasler et al., 2008) and the Lion Ridge (SW ridge, Carell Hut, near surface temperature measurements in the scope of the project PermaDataRock (Pogliotti, 2006).

Surface temperatures were modeled using climate time series from the Corvatsch station in the Upper Engadine (data source: MeteoSwiss), which is located on a summit in a central Alpine climate similar to the Matterhorn area (cf. Gruber et al., 2004b) at $3330 \mathrm{~m}$ a.s.l. This station was chosen because it was shown in previous studies (e.g., Suter, 2002) that horizontal extrapolation of climate variables in mountain areas leads to smaller deviations than vertical extrapolation. Surface properties were used according to the previous simulations (Table 1). The topography was taken from the $25 \mathrm{~m}$ DEM Level 2 by Swisstopo and the FE mesh contained approximately 55000 elements. The lithology of the Matterhorn mainly consists of gneiss and granite of the 


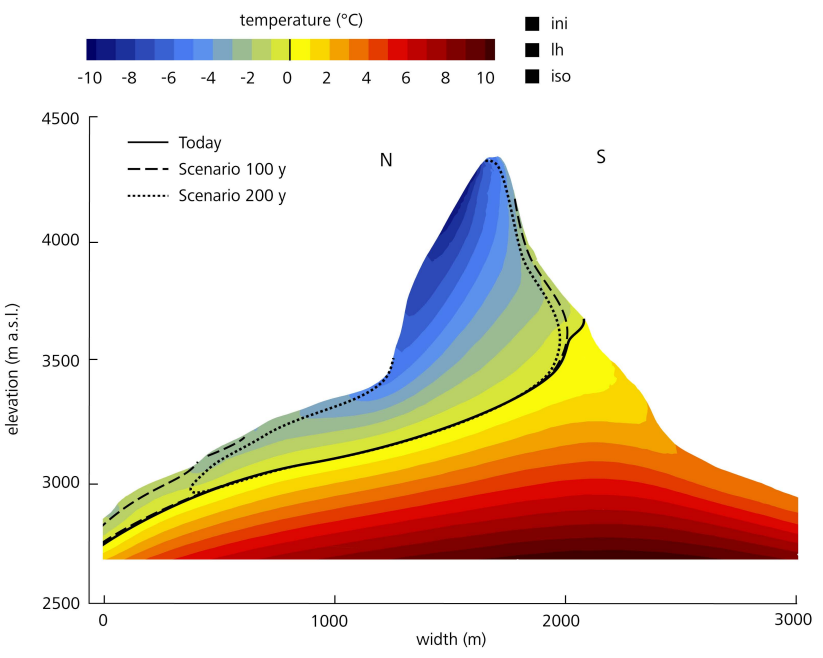

Fig. 12. North-south cross section of the Matterhorn (4478 m a.s.1.) and modeled subsurface temperature field for today (i.e., the mean of the period 1990-1999 AD). The temperature field was computed transient, three-dimensional, isotropic, and with $3 \%$ subsurface ice in the frozen parts. The black lines represent the $0^{\circ} \mathrm{C}$ isotherms for today (solid line), in 100 years (dashed line), and in 200 years (dotted line). We assumed a linear warming scenario of $+3^{\circ} \mathrm{C} / 100 \mathrm{y}$. DHM 25 reproduced by permission of swisstopo (BA091262).

east Alpine Dent-Blanche nappe. We set a thermal conductivity of $2.5 \mathrm{~W} \mathrm{~m}^{-1} \mathrm{~K}^{-1}$, a volumetric heat capacity of $2.2 \times 10^{6} \mathrm{~J} \mathrm{~m}^{-3} \mathrm{~K}^{-1}$, a porosity of $3 \%$, and $w=2$ (cf. Table 1). Boundary conditions and time steps were the same as in the simulations presented above, and anisotropy was not considered.

A north-south cross section through the resulting subsurface temperature field for current conditions and the warming scenario for 200 years is given in Fig. 12. The extreme pyramid-like geometry of the Matterhorn leads to a strongly three-dimensional subsurface temperature field, which is characterized by steeply inclined isotherms, a strong heat flux from the south to the north, and a smaller heat flux from the east to the west face. For present-day conditions and all the simplifications assumed for the simulation, the entire mountain is within permafrost, except for the lower parts of the South side. Additionally considering the idealized scenario, surface temperatures on nearly the entire South side would be positive after 200 years. On the North side, the $0^{\circ} \mathrm{C}$ isotherm at the surface would have risen to an elevation of about $3500 \mathrm{~m}$ a.s.l. The calculated scenario indicates further that possibly substantial permafrost can remain a few decameters below the surface both, on the south and the north side. Temperatures of the remaining sketched permafrost body are warming and the extent of so-called warm permafrost (i.e., about -2 to $0^{\circ} \mathrm{C}$ ) would significantly increase in volume as well as in vertical extent (Fig. 13).

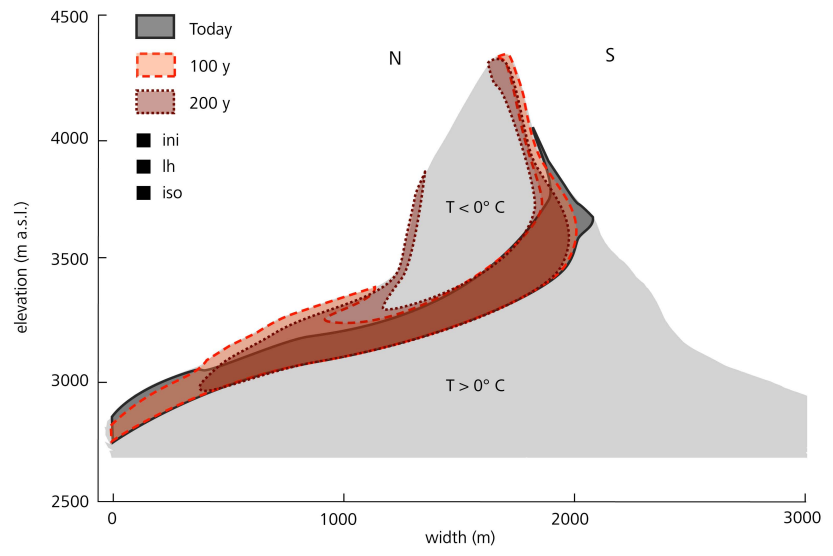

Fig. 13. Modeled temperature range of -2 to $0^{\circ} \mathrm{C}$ in a north-south cross section of the Matterhorn for today (gray), in 100 years (light red), and in 200 years (red). We assumed a linear warming scenario of $+3^{\circ} \mathrm{C} / 100 \mathrm{y}$. DHM 25 reproduced by permission of swisstopo (BA091262).

\section{Discussion}

With the numerical experiments based on simplified mountain topographies having idealized surface and subsurface conditions we analyzed the influence of combined transient and three-dimensional topography effects on the subsurface temperature field in mountain topographies. For the interpretation of the results, a number of uncertainties and limitations of the modeling approach used are important and the simplifications made have to be kept in mind.

Instrumental records of climate parameters are typically available for the past ca. 100 years. Reconstructions of preindustrial climate rely on proxy data and are subject to a great number of uncertainties, which may be even larger than the influence a certain time period has on the subsurface temperatures. In general, climate reconstruction studies agree well on the shape of the climate fluctuations, whereas the absolute amplitude of the temperature variations ranges significantly (Esper et al., 2005). Further, we assumed that changes in GST closely follow air temperatures. Salzmann et al. (2007) demonstrated a considerable influence of topography on the reaction of surface temperatures in steep rock to changing atmospheric conditions. The dimensions of the GST changes, however, are not influenced, and in view of the above-mentioned uncertainties of the reconstructed amplitudes of temperature variations, we consider this effect to be less important for this study.

Much more important are changes in surface cover or surface characteristics, which have been neglected in our idealized simulations. This mainly concerns glacier coverage and the influence of the snow cover. Haeberli (1983) points to higher temperatures at a glacier base than for rock exposed directly to the atmosphere during the past cold periods and, hence, paleoclimatic effects below previously 
glacier-covered areas are likely smaller than in rock directly exposed to the atmosphere during the entire simulation period. This is likely important, for example, for the lower parts of the Matterhorn. In these parts, the temperature field shown in Figs. 12 and 13 has to be interpreted with great care and may considerably deviate in nature. The negligence of the snow cover is a further significant limitation of the modeling approach: Snow cover affects the energy balance at the ground surface by increasing albedo, consuming melt energy, and insulating the ground surface from atmospheric conditions. Snow that remains in steep bedrock can have both, a cooling and a warming effect. For steep rock slopes, however, these effects have not yet been investigated or quantified in detail and results from more gentle terrain cannot be directly transferred to steeper areas (Gruber and Haeberli, 2007). In view of applying the model to less inclined slopes, the influence of a snow cover will have to be included in the model.

In terms of subsurface characteristics, errors induced by uncertain assumptions of thermal conductivity, heat capacity, and heat production increase with depth and length of the simulation, whereas errors caused by uncertainties in subsurface ice decrease. Information on the amount and freezing characteristics of subsurface ice in bedrock is required to improve realistic modeling, but is still scarce. The joint interpretation of numerical model results with data from geophysical monitoring (e.g., electrical resistivity tomography, ERT) has been successfully realized for a first case study of the Schilthorn crest in the Swiss Alps (Noetzli et al., 2008), and information gained in this way may help to improve the representation of the subsurface in the model.

Neglecting water circulation along the joint systems of bedrock is another limitation of the approach used. Advective heat transfer along clefts can contribute, for example, to subsurface heat transfer and lead to thaw corridors in permafrost, which substantially modify a purely conductive system (Gruber et al., 2004a; Gruber and Haeberli, 2007). First applications of geophysical monitoring in solid rock walls recently identified thawed cleft systems influenced by moving water (Krautblatter and Hauck, 2007). Process understanding of advective heat transfer processes in steep bedrock permafrost, however, is limited. But such processes are expected to be important especially in the upper decameters.

We assumed a linear temperature rise of $+3^{\circ} \mathrm{C}$ in $100 \mathrm{y}$ for the calculations of the idealized response of the temperature fields to future changes. An exponential temperature rise as generally proposed for climate change scenarios may slow down the temperature changes calculated. Yet, the temperature increase assumed represents a calculated mean change in GST of Alpine bedrock (Salzmann et al., 2007) and is at the lower range of the scenarios presented for air temperature change by IPCC (2007), where a double temperature raise is not considered unrealistic or extreme for the Alps. The general pattern of a future temperature field that increasingly deviates from steady state conditions and experiences major changes in heat fluxes in the upper ca. 100-200 meters is not affected by these uncertainties.

Because of its temperature range, the acceleration of subsurface temperature changes through multi-lateral warming, and the virtual decoupling from the geothermal heat flux, bedrock permafrost in steep high mountain areas is particularly sensitive to climate change. The simulations of possible future subsurface temperatures with idealized mountain topographies point to long lasting and deep-reaching changes in the subsurface thermal field. For all settings in the experiments, only very little "permafrost" remains at the surface on south-facing Alpine rock slopes in 200 years. Simulated $0^{\circ} \mathrm{C}$-isotherms are about to change to a surfaceparallel course in the top parts of the mountain geometries and then move rather uniformly towards the interior. In terms of temperature-related instabilities such a thawing and horizontally migrating permafrost table may be delicate: rock volumes with temperatures close to the melting point, possibly containing critical ice-water-rock mixtures, increase and may extend over large vertical distances up to entire mountain flanks.

Although our experiments were conducted for strongly idealized conditions, the general pattern and the principal effects shown in this paper can be transferred to real topographies, but keeping in mind the above mentioned uncertainties and the fact that the situation in nature is more complicated and additional processes may be important. For the idealized and simplified present-day temperature field of the Matterhorn, for example, warm permafrost is indicated in the middle part of the South side. In these areas, rock fall events actually have been observed in recent years (2003 and 2006). Looking at the scenario sketched, the zone having temperature little below the freezing point extends over the entire south face and, in addition, over large parts of the north face. Although the modeled temperature field can only be interpreted as a very first approximation to the actual pattern in the Matterhorn, this scenario describes how the surface temperature field may develop in view of future changes in atmospheric conditions.

\section{Conclusions and perspectives}

The results of the simulations performed with idealized test cases of steep mountain topography lead to the following conclusions:

The main variations in surface temperatures that influence present-day subsurface temperatures in Alpine permafrost are the last glacial period and the major temperature variations in the past millennium.

Transient paleothermal effects caused by past climate variations likely exist in the interior of high-mountain peaks. Modeled temperature depressions compared to stationary conditions of present-day GST are in the range of $-3^{\circ} \mathrm{C}$ at 
a distance of $500 \mathrm{~m}$ from the surface and for the idealized model settings.

Transient effects likely become even more important for temperature fields influenced by future warming. Model experiments point to temperature fields that are characterized by long-term and deep reaching perturbations and by temperature patterns that strongly deviate from stationary conditions.

Two- and three-dimensional topography significantly accelerates the pace of a surface temperature signal entering into the subsurface. Together with the fast and unfiltered reaction of its surface to changes in atmospheric conditions and the low ice content, this makes bedrock permafrost in high mountains particularly sensitive to changes.

For the time (20 kyr) and depth (ca. $500 \mathrm{~m}$ ) scales considered, the influence of latent heat on the temperature depressions caused by past GST variations is small in low porosity rock. In view of other sources of uncertainties (e.g., temperature reconstructions) this effect is not considered of major importance. In connection with possible future warming, however, latent heat effects considerably modify the pace of permafrost degradation and the pattern of the subsurface temperature field.

Temperatures of the schematic permafrost body in the geometries are rising when applying the future scenarios, and the extent of "warm permafrost" significantly increases in volume as well as in vertical extent

The distribution and extent of temperatures little below the melting point in a warming subsurface temperature field is significantly influenced by the freezing characteristics of the subsurface material. A small freezing range leads to more homogenous temperature fields and $\mathrm{T}(\mathrm{z})$ profiles with small temperature gradients.

The investigation of mountain permafrost by transient three-dimensional modeling has only been used for a few case studies of real mountain topography so far. It bears potential for various applications that require knowledge of current and future thermal conditions of mountain permafrost, for instance, the reanalysis of the thermal conditions in rock fall starting zones located in permafrost areas, the improved interpretation of $\mathrm{T}(\mathrm{z})$ profiles measured in boreholes, and the assessment of thermal conditions and their evolution in rock below infrastructure. The limitations and uncertainties discussed above call for improved knowledge of subsurface properties in bedrock permafrost, as well as for enhanced validation and modeling practices. A promising approach may be the combination of numerical modeling together with measurements and interpretation of field data. For example, the representation of the subsurface physical properties in the model can be improved by incorporating subsurface information (e.g., geological structures, water/ice content) detected by geophysical surveys. Further, process understanding and incorporation of advective heat transfer and snow remaining in steep rock will be important for a realistic modeling of subsurface temperature fields.
Acknowledgements. This study was supported by the Swiss National Science Foundation, as part of the NF 20-10796./1 project "Frozen rock walls and climate change: transient 3-dimensional investigation of permafrost degradation". Special thanks go to Sven Friedel for support with the COMSOL software and for providing an import routine for DEMs. Fruitful discussions with W. Haeberli and M. Hoelzle (University of Zurich, Switzerland) as well as with T. Kohl (Geowatt AG, Zurich, Switzerland) were valuably contributed to this study. Careful and constructive comments by the two reviewers helped to improve the paper.

Edited by: A. Kääb

\section{References}

Anderson, D. M. and Tice, A. R.: Predicting unfrozen water contents in frozen soils from surface area measurements, Highway Research Record, 393, 12-18, 1972.

Beltrami, H.: On the relationship between ground temperature histories and meteorological records: A report on the Pomquet Station, Global Plaint. Change, 29, 327-348, 2001.

Beltrami, H., Ferguson, G., and Harris, R. N.: Long-term tracking of climate change by underground temperatures, Geophys. Res. Lett., 32, L19707, doi:10.1029/2005GL023714, 2005.

Beniston, M., Diaz, H. F., and Bradley, R. S.: Climatic change at high elevation sites: An overview, Clim. Change, 36, 233-251, 1997.

Beniston, M.: Mountain climates and climate change: An overview of processes focusing on the European Alps, Pure Appl. Geophys., 162, 1587-1606, 2005.

Birch, F.: The effects of Pleistocene climatic variations upon geothermal gradients, Am. J. Sci., 246, 729-760, 1948.

Boehm, R., Auer, I., Brunetti, M., Maugeri, M., Nanni, T., and Schoener, W.: Regional temperature variability in the European Alps: 1760-1998 from homogenized instrumental time series, Int. J. Climatol., 21, 1779-1801, 2001.

Brown, R. J. E. and Péwé, T. L.: Distribution of permafrost in north america and its relationship to the environment, a review 19631973, 2nd International Conference on Permafrost. Proceedings, Yakutsk, USSR, 1973, 71-100, 1973.

Burga, C.: Vegetation history and paleoclimatology of the middle Holocene: Pollen analysis of Alpine peat bog sediments, covered formerly by the Rutor Glacier, 2510 m (Aosta Valley, Italy), Global Ecol. Biogeogr., 1, 143-150, 1991.

Carslaw, H. S. and Jaeger, J. C.: Conduction of heat in solids, Oxford science publications, Clarendon Press, Oxford, 510 pp., 1959.

Casty, C., Wanner, H., Luterbacher, L., Esper, J., and Boehm, R.: Temperature and precipitation variability in the European Alps since 1500, Int. J. Climatol., 25, 1855-1880, 2005.

Cermák, V. and Rybach, L.: Thermal conductivity and specific heat of minerals and rocks, in: Landolt-börnstein Zahlenwerte und Funktionen aus Naturwissenschaften und Technik, neue Serie, physikalische Eigenschaften der Gesteine (v/1a), edited by: Angeneister, G., Springer, Berlin, 305-343, 1982.

Crowley, T. J. and Lowery, T. S.: How warm was the Medieval Warm Period? Ambio, 29, 51-54, 2000.

Dahl-Jensen, D., Modegaard, K., Gundestrup, N., Clow, G. D., Johnsen, S. J., Hansen, A. W., and Balling, N.: Past temperatures 
directly from the Greenland Ice Sheet, Science, 282, 268-271, 1998.

Davies, M. C. R., Hamza, O., and Harris, C.: The effect of rise in mean annual temperature on the stability of rock slopes containing ice-filled discontinuities, Permafrost Periglac., 12, 137-144, 2001.

Esper, J., Wilson, R. J. S., Frank, D. C., Moberg, A., Wanner, H., and Luterbacher, J.: Climate: Past ranges and future changes, Quarternary Sci. Rev., 24, 2164-2166, 2005.

Goosse, H., Arzel, O., Luterbacher, J., Mann, M. E., Renssen, H., Riedwyl, N., Timmermann, A., Xoplaki, E., and Wanner, H.: The origin of the European "Medieval Warm Period", Clim. Past, 2, 99-113, 2006,

http://www.clim-past.net/2/99/2006/.

Gruber, S., Hoelzle, M., and Haeberli, W.: Permafrost thaw and destabilization of Alpine rock walls in the hot summer of 2003, Geophys. Res. Lett., 31, L13504, doi:10.1029/2004GL0250051, 2004a.

Gruber, S., Hoelzle, M., and Haeberli, W.: Rock wall temperatures in the Alps: Modeling their topographic distribution and regional differences, Permafrost Periglac., 15, 299-307, 2004 b.

Gruber, S., King, L., Kohl, T., Herz, T., Haeberli, W., and Hoelzle, M.: Interpretation of geothermal profiles perturbed by topography: The Alpine permafrost boreholes at Stockhorn Plateau, Switzerland, Permafrost Periglac., 15, 349-357, 2004c.

Gruber, S.: Mountain permafrost: Transient spatial modelling, model verification and the use of remote sensing, $\mathrm{PhD}$ Thesis, Department of Geography, University of Zurich, Zurich, 2005.

Gruber, S., and Haeberli, W.: Permafrost in steep bedrock slopes and its temperature-related destabilization following climate change, J. Geophys. Res., 112, F02S18, doi:10.1029/2006JF000547, 2007.

Haeberli, W.: Permafrost-glacier relationships in the Swiss Alps - today and in the past, 4th International Conference on Permafrost. Proceedings, Fairbanks, Alaska, 1983, 415-420,

Haeberli, W., Rellstab, W., and Harrison, W. D.: Geothermal effects of $18 \mathrm{ka}$ BP ice conditions in the Swiss Plateau, Ann. Glaciol., 5, 56-60, 1984.

Haeberli, W.: Construction, environmental problems and natural hazards in periglacial mountain belts, Permafrost Periglac., 3, 111-124, 1992.

Haeberli, W., Wegmann, M., and Vonder Mühll, D.: Slope stability problems related to glacier shrinkage and permafrost degradation in the Alps, Eclogae Geol. Helv., 90, 407-414, 1997.

Haeberli, W. and Beniston, M.: Climate change and its impacts on glaciers and permafrost in the Alps, in: Ambio - a journal of the human environment, edited by: Rapp, A., and Kessler, E., 4, The Royal Swedish Academy of Sciences, 258-265, 1998.

Harris, C., Davies, M. C. R., and Etzelmüller, B.: The assessment of potential geotechnical hazards associated with mountain permafrost in a warming global climate, Permafrost Periglac., 12, 145-156, 2001.

Hasler, A., Talzi, I., Beutel, J., Tschudin, C., and Gruber, S.: Wireless sensor networks in permafrost research: Concept, requirements, implementation, and challenges, 9th International Conference on Permafrost, Fairbanks, US, 669-674, 2008.

Hauck, C., Bach, M., and Hilbich, C.: A 4-phase model to quantify subsurface ice and water content in permafrost regions based on geophysical datasets, 9th International Conference on Per- mafrost, Fairbanks, US, 675-680, 2008.

Huang, S., Pollak, H. N., and Shen, P. Y.: Temperature trends over the last five centuries reconstructed from borehole temperatures, Nature, 403, 756-758, 2000.

Hughes, M. K., and Diaz, H. F.: Was there a "Medieval Warm Period", and if so, where and when?, Clim. Change, 26, 109-142, 1994.

IPCC: Climate change 2007: The physical science basis. Contribution of working group I to the fourth assessment report of the Intergovernmental Panel on Climate Change, edited by: Solomon, S., Qin, D., Manning, M., Chen, Z., Marquis, M., Averyt, K. B., Tignor, M., and Miller, H. L., Cambridge University Press, Cambridge, United Kingdom and New York, 996 pp., 2007.

Isaksen, K., Vonder Mühll, D., Gubler, H., Kohl, T., and Sollid, J. L.: Ground surface temperature reconstruction based on data from a deep borehole in permafrost at Janssonhaugen, Svalbard, Ann. Glaciol., 31, 287-294, 2000.

Isaksen, K., Sollid, J. L., Holmlund, P., and Harris, C.: Recent warming of mountain permafrost in Svalbard and Scandinavia, J. Geophys. Res., 112, F02S04, doi:10.1029/2006JF000522, 2007.

Jones, P. D., Briffa, K. R., Barnett, T. P., and Tett, S. F. B.: Highresolution paleoclimatic records for the last millennium: Interpretation, integration, and comparison with general circulation model control-run temperatures, Holocene, 8, 455-471, 1998.

Jones, P. D. and Mann, M. E.: Climate over past millennia, Rev. Geophys., 42, RG2002, doi:2010.1025/2003RG000143, 2004.

Kohl, T.: Transient thermal effects at complex topographies, Tectonophysics, 306, 311-324, 1999.

Kohl, T., Signorelli, S., and Rybach, L.: Three-dimensional (3-D) thermal investigation below high Alpine topography, Phys. Earth Plaint. In., 126, 195-210, 2001

Kohl, T. and Gruber, S.: Evidence of paleaotemperature signals in mountain permafrost areas, 8th International Conference on Permafrost, Extended Abstracts, Zürich, 83-84, 2003.

Krautblatter, M. and Hauck, C.: Electrical resistivity tomography monitoring of permafrost in solid rock walls, J. Geophys. Res., 112, F02S20, doi:10.1029/2006JF000546, 2007.

Kukkonen, I. T. and Safanda, J.: Numerical modelling of permafrost in bedrock in northern Fennoscandia during the Holocene, Glob. Plaint. Change, 29, 259-273, 2001.

Lachenbruch, A. H. and Marshall, B. V.: Changing climate: Geothermal evidence from permafrost in the alaskan arctic, Science, 234, 689-696, 1986.

Lüthi, M. and Funk, M.: Modelling heat flow in a cold, high-altitude glacier: Interpretation of measurements from Colle Gnifetti, Swiss Alps, J. Glaciol., 47, 314-324, 2001.

Lunardini, V. J.: Climatic warming and the degradation of warm permafrost, Permafrost Periglac., 7, 311-320, 1996.

Luterbacher, J., Dietrich, D., Xoplaxi, E., Grosjean, M., and Wanner, H.: European seasonal and annual temperature variability, trends and extremes since 1500, Science, 303, 1499-1503, 2004

Medici, F. and Rybach, L.: Geothermal map of Switzerland 1995 (heat flow density), Géophysique 30, Schweizerische Geophysikalische Kommission, 1995.

Mottaghy, D. and Rath, V.: Latent heat effects in subsurface heat transport modeling and their impact on paleotemperature reconstructions, Geophys. J. Int., 164, 236-245, 2006.

Noetzli, J.: Modeling transient three-dimensional temperature fields in mountain permafrost, PhD Thesis, Department of Geography, 
University of Zurich, Zurich, 150 pp., 2008.

Noetzli, J., Hoelzle, M., and Haeberli, W.: Mountain permafrost and recent Alpine rock-fall events: A GIS-based approach to determine critical factors, 8th International Conference on Permafrost, Proceedings, Zürich, 827-832, 2003.

Noetzli, J., Gruber, S., and Friedel, S.: Modeling transient permafrost temperatures below steep Alpine topography, COMSOL User Conference, Grenoble, 139-143, 2007a.

Noetzli, J., Gruber, S., Kohl, T., Salzmann, N., and Haeberli, W.: Three-dimensional distribution and evolution of permafrost temperatures in idealized high-mountain topography, J. Geophys. Res., 112, F02S13, doi:10.1029/2006JF000545, 2007b.

Noetzli, J., Hilbich, C., Hauck, C., Hoelzle, M., and Gruber, S.: Comparison of simulated 2D temperature profiles with timelapse electrical resistivity data at the Schilthorn crest, Switzerland., 9th International Conference on Permafrost, Fairbanks, US, 2008, 1293-1298.

Patzelt, G.: Neue Ergebnisse der Spät- und Postglazialforschuung in Tirol, in: Jahresbericht, Österreichische Geographische Gesellschaft, Zweigverein Innsbruck, 11-18, 1987.

PERMOS: Permafrost in Switzerland 2002/2003 and 2003/2004, Glaciological report (Permafrost) no. $4 / 5$ of the Cryospheric Commission of the Swiss Academy of Sciences (SCNAT) and Department of Geography, University of Zurich, edited by: Vonder Muehll, D., Noetzli, J., Roer, I., Makowski, K., and Delaloye, R., 104 pp., 2007.

Petit, J. R., Jouzel, J., Raynnaud, D., Barkov, N. I., Barnola, J.-M., Basile, I., Bender, M., Chappellaz, J., Davis, M., Delaygue, G., Delmotte, M., Kotlyakov, V. M., Legrand, M., Lipenkov, V. Y., Lorius, C., Pépin, L., Ritz, C., Saltzman, E., and Stievenard, M.: Climate and atmospheric history of the past 420000 years from the Vostok ice core, Antarctica, Nature, 399, 429-436, 1999.

Pfister, C.: Wetternachhersage, Haupt, Bern, 304 pp., 1999.

Pogliotti, P.: Analisi morfostrutturale e caratterizzazione termica di ammassi rocciosi recentemente deglaciati. MSc Thesis, Heart Science Department, University of Turin, Turin, 191 pp., 2006.

Pollak, H. N., Huang, S., and Shen, P. Y.: Climate change record in subsurface temperatures: A global perspective, Science, 282, 279-281, 1998.

Pollak, H. N. and Huang, J.: Climate reconstruction from subsurface temperatures, Ann. Rev. Earth Plaint. Sci., 28, 339-365, 2000.

Romanovsky, V. E. and Osterkamp, T. E.: Effects of unfrozen water on heat and mass transport processes in the active layer and permafrost, Permafrost Periglac., 11, 219-239, 2000.
Romanovsky, V. E., Gruber, S., Instanes, A., Jin, H., Marchenko, S. S., Smith, S. L., Trombotto, D., and Walter, K. M.: Frozen ground, in: Global outlook for ice and snow, edited by: UNEP, UNEP/GRID-Arendal, Norway, 182-200, 2007.

Safanda, J.: Ground surface temperature as a function of slope angle and slope orientation and its effect on the subsurface temperature field, Tectonophysics, 306, 367-375, 1999.

Safanda, J. and Rajver, D.: Signature of the last ice age in the present subsurface temperatures in the Czech Republic and Slovenia, Glob. Plaint. Change, 29, 241-257, 2001.

Salzmann, N., Noetzli, J., Gruber, S., Hauck, C., and Haeberli, W.: RCM-based ground temperature scenarios in high-mountain topography and their uncertainty ranges, J. Geophys. Res., 112, F02S12, doi:10.1029/2006JF000527, 2007.

Scherler, M.: Messung und Modellierung konvektiver Wärmetransportprozesse in der Auftauschicht von Gebirgspermafrost am Beispiel des Schilthorns, Department of Geography, University of Zurich, Zurich, 94 pp., 2006.

Schoen, J.: Petrophysik, Ferdinand Enke, Stuttgart, 1983.

Stocker-Mittaz, C.: Permafrost distribution modeling based on energy balance data. PhD-Thesis, Department of Geography, University of Zurich, Zurich, 122 pp., 2002.

Suter, S.: Cold firn and ice in the monte rosa and mont blanc areas: spatial occurrence, surface energy balance and climatic evidence, 172, Versuchsanstalt für Wasserbau, Hydrologie und Glaziologie der ETH Zürich, ETH Zürich, Zürich, 188 pp., 2002.

Von Rudloff, H.: Das Klima - Entwicklung in den letzten Jahrhunderten im mitteleuropäischen Raume (mit einem Rückblick auf die postglaziale Periode), in: Das Klima - Analysen und Modelle, Geschichte und Zukunft, edited by: Oeschger, H., Messerli, B., and Silvar, M., Springer, Berlin, 125-148, 1980.

Washburn, A. L.: Geocryology - a survey of periglacial processes and environments, edited by: Quartenary Research Center, U. o. W., Edward Arnold Ltd., London, 406 pp., 1979.

Wegmann, M.: Frostdynamik in hochAlpinen Felswänden am Beispiel der Region Jungfraujoch-Aletsch, 161, Versuchsanstalt für Wasserbau, Hydrologie und Glaziologie der ETH Zürich, ETH Zürich, Zürich, 143 pp., 1998.

Wegmann, M., Gudmundsson, G. H., and Haeberli, W.: Permafrost changes in rock walls and the retreat of Alpine glaciers: A thermal modelling approach, Permafrost Periglac., 9, 23-33, 1998.

Williams, P. J. and Smith, M. W.: The frozen earth, 1 ed., Studies in polar research, Cambridge University Press, Cambridge, 306 pp., 1989. 